\title{
Expression of Concern to: The role of ACE2, angiotensin-(1-7) and Mas1 receptor axis in glucocorticoid-induced intrauterine growth restriction
}

Elham Ghadhanfar ${ }^{1}$, Aseel Alsalem², Shaimaa Al-Kandari ${ }^{2}$, Jumana Naser ${ }^{2}$, Fawzi Babiker ${ }^{1}$ and Maie Al-Bader ${ }^{1 *}$

Expression of Concern to: Reprod Biol Endocrinol 15, 97 (2017)

https://doi.org/10.1186/s12958-017-0316-8

The Editors-in-Chiefare issuing an Expression of Concern for this article [1]. After publication concerns were raised with respect to the specificity and validity of the placental Ang-(1-7) levels assessed by Western blotting and reported in Fig. 4 because Ang-(1-7), which is less than $1 \mathrm{kDa}$, was detected as a $34 \mathrm{kDa}$ protein. All authors disagree with this Expression of Concern.

\section{Author details}

${ }^{1}$ Department of Physiology, Faculty of Medicine, Kuwait University, Kuwait

City, Kuwait. ${ }^{2}$ Faculty of Medicine, Kuwait University, Kuwait City, Kuwait.

Published online: 25 May 2020

\section{Reference}

1. Ghadhanfar E, Alsalem A, Al-Kandari S, et al. The role of ACE2, angiotensin-

(1-7) and Mas1 receptor axis in glucocorticoid-induced intrauterine growth restriction. Reprod Biol Endocrinol. 2017;15:97. https://doi.org/10.1186/ s12958-017-0316-8.

* Correspondence: albader@hsc.edu.kw

'Department of Physiology, Faculty of Medicine, Kuwait University, Kuwait City, Kuwait

Full list of author information is available at the end of the article

Ready to submit your research? Choose BMC and benefit from:

- fast, convenient online submission

- thorough peer review by experienced researchers in your field

- rapid publication on acceptance

- support for research data, including large and complex data types

- gold Open Access which fosters wider collaboration and increased citations

- maximum visibility for your research: over $100 \mathrm{M}$ website views per year

At BMC, research is always in progress.

Learn more biomedcentral.com/submissions

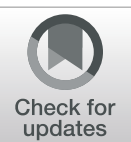

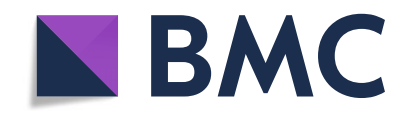

() The Author(s). 2020 Open Access This article is licensed under a Creative Commons Attribution 4.0 International License, which permits use, sharing, adaptation, distribution and reproduction in any medium or format, as long as you give appropriate credit to the original author(s) and the source, provide a link to the Creative Commons licence, and indicate if changes were made. The images or other third party material in this article are included in the article's Creative Commons licence, unless indicated otherwise in a credit line to the material. If material is not included in the article's Creative Commons licence and your intended use is not permitted by statutory regulation or exceeds the permitted use, you will need to obtain permission directly from the copyright holder. To view a copy of this licence, visit http://creativecommons.org/licenses/by/4.0/. The Creative Commons Public Domain Dedication waiver (http://creativecommons.org/publicdomain/zero/1.0/) applies to the data made available in this article, unless otherwise stated in a credit line to the data. 